\title{
Women's Citizenship and Neopopulism: Peru Under the Fujimori Regime
}

\author{
Stéphanie Rousseau
}

\begin{abstract}
This article argues that the increased participation of women in Peruvian politics in the 1990s and the advances made in some areas of their citizenship rights are connected to the strategies put in place by some sectors of the women's movement and to the openings provided by the Fujimori regime. Some of the impact of neopopulist rule on political institutions is shown to be positively related to women's increased opportunities during this period; yet the weak rule of law and the political use of the women's agenda by an increasingly questionable regime placed the women's movement in a complex political panorama. A disaggregated analysis of the politics of women's citizenship reveals that women from the popular sectors did not benefit from the same progress in their rights claims as women from the feminist movement or women in party politics.
\end{abstract}

W hat isn't good for democracy isn't good for women," said the slogan that became central in the struggle of Mujeres por la Democracia (Women for Democracy), a civil society movement of Peruvian women from various sectors who mobilized in the last years of the Alberto Fujimori regime (1990-2000) to expose its authoritarian character. Yet throughout the $1990 \mathrm{~s}$, a number of trends suggested that during this regime, women's citizenship rights made significant advances.

Although Peru returned to democratic rule in 1980 with universal suffrage for the first time, the 1990 s were marked by the authoritarian character of Fujimori, an elected neopopulist civilian who radically transformed the Peruvian political landscape. The politics of women's citizenship rights were one aspect of the troubled political process in Peru, and they certainly contributed to legitimating Fujimori's regime to some extent in the eyes of some sections of the population. As a result, the women's movement had to struggle to maintain its autonomy while benefiting from the opportunities offered to push forward some of its rights claims.

The literature on the role of women's movements in the events leading to the breakdown of authoritarian regimes and transitions to democracy in Latin America has shown that these movements were among the first actors to initiate the mobilization of civil societies against military regimes, and that they enjoyed greater freedom than parties or 
unions, which suffered from more severe repression and control (Jaquette 1989; Alvarez 1990; Jaquette and Wolchik 1998; Waylen 1994). Once the transitions to democracy of the 1980 s had led to relatively enduring democratic regimes, another assessment was made of the space occupied by women's movements in the new political framework. The pattern revealed in most cases, such as Argentina, Chile, and Brazil, was a retreat of women's movements from the center of politics with the return of political parties. The gains women made during the transition period, more successful in some cases than others, stagnated or suffered reversals under the new democratic regimes.

Electoral politics clearly posed new challenges for women trying to remain central political actors, according to most of the literature (Jaquette 1994; Friedman 2000; Waylen 2000). Democracy was not as friendly to women as could have been expected. Yet some progress was noted in the 1990s in women's citizenship rights, such as the adoption of gender electoral quotas to increase women's participation as candidates or the creation of state agencies devoted to developing gender-sensitive policies and eradicating gender discrimination (Htun and Jones 2002).

This study seeks to advance the exploration of the relationship between women's movements and the nature of the "actually existing democratic regimes" in Latin America. The case of Peru under Fujimori illustrates the tensions and contradictions embedded in the interaction between organized women in civil society, representative institutions, and the state on key issues put forward by women to advance their citizenship rights. While this case differs from other cases in the literature dealing with Latin American women's political participation in posttransition politics because of the very circumscribed democratic character of this regime, some useful comparisons can still be made. After all, Peru under Fujimori continued to be ruled by elected authorities, political parties were allowed to function, and elections were regularly held. Freedom of expression and association, while curtailed at times, were theoretically upheld by the regime. An examination of the record of Peruvian women in the public sphere and on the political agenda under a formally democratic regime with strong authoritarian features offers some interesting conclusions about the respective roles of civil society, political institutions, and the state in the politics of women's citizenship rights. Indeed, the reality of democracy in other Latin American countries sometimes comes close to that of Peru during Fujimori's regime, and can be compared on various counts.

Following Georgina Waylen's proposed "gendered analysis of institutions," this study furthers the comparative study of Latin American women's movements' impact on national political institutions by examining how the structure and rules that characterize these institutions actually shape and modify gender relations, thereby affecting women's 
citizenship positively or negatively (Waylen 2000). The perspective adopted here is that of the social construction of citizenship, which, when applied to women, adopts a gender-sensitive analysis of rights and looks at how women, as political actors, define their rights claims and seek their recognition by the state (Oxhorn 1998). Besides the women's movement and the institutional framework, the influence of international factors and the strategies put forward by Fujimori himself concerning women's issues form part of the explanation for the pattern of women's rights' advances and losses.

While women benefited from the Fujimori era by making important gains in their access to the political sphere and significant legislative reforms, the trade-offs caused by the need to operate in an "electoral authoritarian" (Carrión 2001) or "competitive authoritarian" (Levitsky and Way 2002) framework were numerous and risky, leading to disillusionment and divisions in the women's movement. While advances were made in civil and political rights, moreover, a disaggregated analysis of the progress of Peruvian women's citizenship in the 1990s reveals a highly unequal record for women of the lower classes, for whom poverty was a daily source of violation of their citizenship rights and for which Fujimori's neoliberal program did not provide any sustainable solution.

This discussion is framed by the notion of neopopulism as developed in some of the recent literature on Latin American politics. The Fujimori regime can be understood as a form of neopopulist rule. The setbacks of the popular sector women's movement and the losses in social and economic rights are related to the particular combination of neopopulism and neoliberalism that characterized the Fujimori regime.

\section{FuJIMORISMo, OR NEOPOPULIST RULE IN THE 1990S}

The Fujimori regime is particularly challenging from a theoretical point of view in light of the difficulty of categorizing it after Fujimori's 1992 self-coup. ${ }^{1}$ Beyond the coup's authoritarian character and its illegal abrogation of the constitutional order, what was also at stake was the institutional and political framework Fujimori had established in an attempt to appease international criticism and provide the foundations of a new, so-called democratic regime.

The Fujimori regime emerged in response to acute problems in the political system that had rendered its political institutions vulnerable: years of insurgent and counterinsurgent violence, the failure of President Alan Garcia's economic populism in the late 1980s, the extreme division and disappearance of the democratic left, and the subsequent weakening of the popular movement. All these factors accounted for the 
Fujimori regime's capacity to impose its own blend of authoritarianism on a formally democratic framework.

Referring to the minimal definition of democracy, which focuses on the conditions for and occurrence of free and fair elections, Cynthia McClintock (1999) and Gregory Schmidt (2000) have both raised serious doubts about whether the post-1993 Fujimori regime could be qualified as a democracy at all, with or without adjectives, considering how much the regime actually controlled the judiciary, the electoral bodies, and a large portion of the media; used state agencies and resources for the benefit of Fujimori's electoral campaigns; and resorted to blackmail and threats against political opponents.

To legitimate his new constitution, drafted in 1993, Fujimori submitted it to popular approval through a referendum, which received a slim majority vote. The new constitution, aside from preparing the ground to institutionalize the government's neoliberal reform agenda, also allowed the president to run for a second mandate. The 1995 elections reinstalled Fujimori with a very comfortable majority because of his success in fighting the war against Sendero Luminoso (the capture of Abimael Guzmán, Sendero's charismatic leader, in 1993 was one of the regime's greatest achievements) and in controlling the economic crisis. Those elections, however, were marked by irregularities in the legislative results. The consolidation of a powerful web of corruption under the control of Vladimiro Montesinos, a "presidential adviser" who actually headed the national intelligence services and was perceived as the real power over and above Fujimori, became a central feature of this regime.

The regime's increasingly authoritarian nature was starkly revealed when Fujimori sought to be "re-reelected" in 2000, in violation of the constitution he himself had put forward. In the late 1990s, he resorted to flagrant interference and manipulation of the judiciary and the congress in order to craft a "legal" opportunity to run again. Even so, it was revealed during the 2000 electoral campaign that Fujimori had installed a secret "factory" for forging signatures in order to register his Perú 2000 as an official party. This and other serious problems during the elections confirmed the lack of transparency or fairness in the electoral process (Transparencia 2000). Following a contested election and under increased national and international scrutiny and pressure, the regime finally broke down because of corruption and bribery scandals in the months following Fujimori's May 2000 reelection.

The range of terms and definitions of democracy and authoritarianism that have developed in reaction to the observed reality of the new "democratic" regimes in Latin America and elsewhere are thus tested in a particularly vivid way when analyzing Peruvian politics in the 1990s. The post-1992 Fujimori regime has been described alternatively as a "degenerate delegative democracy" (O'Donnell 1994; Cameron and 
Mauceri 1997), a "formal democracy" (Stokes 1996), a "semidemocracy" (Levitsky 1999), and a "pseudodemocracy" (Diamond 1996). In contrast, most Peruvian analysts have simply termed it "increasingly authoritarian." They use the term fujimorismo to describe the regime's particular authoritarian nature while underscoring the existence of the formal institutions of democracy and the rights and freedoms-mainly civil and political-associated with it (Rospigliosi 1995; Cotler 1995; Cotler and Grompone 2000; Carrión 2001).

Similarly, Levitsky and Way propose the notion of "competitive authoritarianism" to describe regimes such as Fujimori's, whereby "formal democratic institutions are widely viewed as the principal means of obtaining and exercising political authority," yet "incumbents violate those rules so often and to such an extent that the regime fails to meet conventional minimum standards for democracy" (Levitsky and Way 2002, 52). The criteria used by Levitsky and Way to distinguish competitive authoritarian regimes from pure forms of authoritarianism rely on the effective functioning of "four arenas of democratic contestation": the electoral, legislative, judicial, and media spheres. While these arenas are the object of constant manipulation by the authoritarian authorities, they are used with equal consistency by political opponents or civil society to expose the regime's authoritarian character. Ultimately, the survival of a competitive authoritarian regime is threatened by the unpredictability of the political process and the need to resort to increased control and repression, leading to a critical level of violation of democratic rules that eventually becomes unsustainable.

Another way to understand the consequences of fujimorismo for the political system is to follow Roberts's proposed definition of neopopulism to characterize the particular mode of interest mediation and political rule exercised by such a regime (Roberts 1995). Among the principal traits of neopopulist rule that echo those of more "traditional" populism Roberts underlines "a personalistic style of leadership, a heterogeneous social constituency with widespread lower-class support, and the absence of institutionalized forms of political mediation between the leader and his followers" (Roberts 1995, 92). Although the political party system was already in crisis in 1990, when Fujimori was first elected, the neopopulist regime that took hold contributed directly to deepening the crisis of political representation and seriously eroding the separation of powers. This it did mainly through constant attacks by power incumbents on political parties and other organizations in civil society, so as to reduce the chances for meaningful autonomous organization; an extensive process of deinstitutionalization and centralization of power in the hands of the president; and the personalistic leader's appeals directly to the masses, with ample use of popular culture references. 
However, Roberts and Weyland, among others, also show that neopopulist rule differs from traditional populism, which typically relies on a set of economic policies associated with the model of import-substituting industrialization, such as progressive redistributive policies. Neopopulist rule, on the other hand, is reconcilable with either neoliberal or other types of economic policies (Roberts 1995; Weyland 1996, 1999, 2001). ${ }^{2}$ The channels of political support and clientelism between the Fujimori regime and popular sectors thus were consolidated through the design of a number of social compensation programs aimed at providing immediate but limited material rewards-in the form of food donations or housing ownership titles, for example-to the poorest sectors of Peruvian society, as part of the policies accompanying the implementation of International Monetary Fund-style adjustment and liberalization programs. With no solid mechanisms for mass mobilization, Fujimori was nonetheless able to remain very popular in low-income sectors through careful use of targeted social assistance and control over a large portion of the mass media. The latter portrayed the president as the defender of the poor against the "privileges" of the traditional political class and against the perils of leftist political forces, which most of the media indiscriminately associated with insurgent violence.

It is also significant that the international community generally supported Fujimori until the very end of his rule. Until the regime broke down, it was very difficult to foresee its end, not to mention the strategies that could be implemented to oppose it successfully, even if numerous individuals and organizations devoted their energies to achieving this goal throughout the 1990s and more intensely in the last years of his rule. This placed women's organizations, and women as individual citizens, in the position of adopting both oppositional and accommodative strategies in their relationship with the regime. The complexity of qualifying Peru's political regime in the 1990s is reflected in this latter dimension of direct political experience, showing that what was at stake was more than just a theoretical exercise.

\section{Advances in Women's CitizenshiP}

A few scholars have already underscored the important role taken by women in the political sphere under the regime of Fujimori, together with new developments on some issues of particular concern to women (Blondet 1998, 1999a, 2002; Klatzer 2000; Rousseau 2001, 2004, 2005; Schmidt forthcoming). Fujimori showed a particular interest in emphasizing women's contribution to Peruvian society in what seemed to be an attempt to increase his credentials as a modernizing leader. The promotion of women's participation in electoral politics through the adoption of gender quotas for legislative and municipal elections, and the 
high priority the regime accorded to public family planning services, among other matters, were used to show that fujimorismo was "more democratic" than all previous regimes in Peru.

A notable feature of the Fujimori regime was the greater number of professional women who were appointed to key positions in the bureaucracy, the foreign service, and the judiciary. ${ }^{3}$ In the lists of candidates presented by Fujimori's successive political "movements" in the various elections during the 1990 s, women were generally present in proportions similar to those in opposition parties; but female candidates on Fujimori's lists generally obtained greater popularity than those on opposition parties' lists. ${ }^{4}$ These women, the group of fujimorista congresswomen in particular, acted as very visible and loyal spokespersons who defended the regime and portrayed the president as a "good father" for the people of Peru (Blondet 2002; Schmidt forthcoming). Beyond the obvious conservative character of this image, the label represented the need for order and stability expressed by the majority of women in the early 1990s while Peru was enmeshed in its worst economic and political crisis ever.

The clauses providing for electoral gender quotas, which were discussed as part of the many projects to reform the electoral code and the municipal elections law in 1995 and 1996 and ultimately adopted in 1997 , led the way to increased representation of women in Congress and municipal government. The obligation to nominate a minimum of 25 percent of candidates of both genders in electoral lists for Congress was accepted after a lengthy debate on different proposals that revealed the technical complexity and the political sensitiveness of such reform. The formula ultimately adopted was originally presented by an opposition congresswoman but later resubmitted by a fujimorista. It had the advantage of introducing a gender-blind quota by establishing a required minimum number of candidates of both sexes, thus bypassing the critics who denounced the quota as a discriminatory measure. In a similar fashion, the mandatory quota for municipal electoral lists was also set at 25 percent in $1997 . .^{5}$

This development was one of the most important legal and political victories of the women's movement, which had first proposed the adoption of electoral gender quotas in 1994. The impact of the quotas was felt immediately. After the 1998 municipal elections, women's share of municipal council seats increased from 8.5 percent in 1995 to 21 percent in 1998 (Blondet 2002, 85). As for congresswomen, their share increased from 10.8 percent in 1995 to 21.7 percent in 2000 (Blondet 2002, 77). Women's share of seats in the legislature since the return to democracy had remained relatively constant in a range between 10.5 percent and 12.3 percent. The increase in 2000 was therefore significant. ${ }^{6}$ 
One of the key actors promoting these quotas was the permanent congressional Commission on Women, created in 1995 with the mandate to review and propose bills on issues of particular relevance to women. The commission became an important venue for the collaboration of congresswomen from different parties, including Fujimori's. In the words of its first president, opposition politician Beatriz Merino, the commission was one of the rare institutional organizations in which a majority of congress members shared a clear agenda (Merino 2001). The numerous bills proposed by the commission, some of which Congress later adopted, resulted from this exceptional level of interparty collaboration between congresswomen, with the input of prominent feminist activists from civil society organizations.

On the side of state institutions, important developments also helped to highlight women's issues in the political sphere. A Ministry for the Promotion of Women and Human Development (PROMUDEH) was established in 1996, the first of its kind in Peru and the first cabinet-level portfolio ministry on women in Latin America. A specialized unit on women's rights in the national ombudsman's office was also set up in the same period. While some of these developments stemmed from the political determination of key public figures who did not necessarily support the regime, the promotion of women became a central part of the agenda of Fujimori's institutions, and the president's initiative or support was instrumental in all these instances.

Some important legal reforms favoring women's rights were adopted by a Congress dominated by a majority composed of Fujimori's political forces. First, the law "on the policy of the state and society on domestic violence," approved in December 1993, provided, for the first time in Peru and among the first in Latin America, a legal framework to address domestic violence. It also provided the means for the state to protect victims and sanction perpetrators. It came about as the result of prolonged work and advocacy by women's rights organizations in civil society.

The modification of the penal code was also a central objective pursued by the women's movement from the late $1980 \mathrm{~s}$ on. The previous code contained serious problems related to the definition of the crime of rape, the status of women as victims of rape and sexual violence, and the responsibility of the state in protecting victims and punishing perpetrators. An early reform in 1991 provided some corrections, yet some important areas were left untouched. One was a norm that absolved a perpetrator of rape from penal sanction if he subsequently married the victim. A bill presented by Congresswoman Merino in March 1996 sought to eradicate such a norm; it was adopted in April 1997.

Another significant modification of the penal code made public prosecution mandatory in cases of sexual violence. Before this, prosecution was left to the initiative and resources of the victims themselves. 
Two bills were presented by opposition congresswomen Merino and Ana-Elena Townsend in 1998. A law was adopted in May 1999 as a result of an extensive campaign jointly run by feminist NGOs, women in key government positions, the media, and the two congresswomen, together with other legislators appointed to the Commission on Women, headed during that period by a congresswoman from Fujimori's party.

All these reforms were approved despite the losses in the field of women's rights caused by erasing or replacing some articles in the constitution. A number of key articles of the 1979 Constitution, such as one that explicitly called for equal pay for equal work and another that declared the right to equal opportunities for men and women, which more broadly affirmed that women should not have lesser rights than men, were replaced by a general article rendering all kinds of discrimination-based on sex, race, language, religion, and so on-contrary to the constitution. This amounted to a weakening of the principle of substantial gender equality that allowed the implementation of affirmative action measures and a return to a formal definition of equality before the law. Earlier, Peru had ratified important international instruments on women's human rights, which meant that some affirmative action measures could still be considered not contrary to the nondiscrimination article when shown to be temporal and geared toward ending systemic inequality (Dános Ordoñez 2000). The electoral gender quotas constitute the only example of such measures implemented after the adoption of the 1993 Constitution.

\section{The Peruvian Women's Movement}

Most of the positive initiatives and developments favoring women's increased access to the political sphere and enhanced civil rights emerged in relation to the sustained work of a wide network of organized women in Peruvian civil society that increasingly addressed the state and the mainstream political sphere from the mid-1980s on. While the women's movement was formed from various branches with different types of memberships and orientations, only some of those groups managed to find some echo of their claims in the policies and decisions of the highest political authorities in the 1990s.

Broadly speaking, the women's movement in Peru comprises three general branches, according to most analysts and participants (Barrig 1994; Vargas and Villanueva 1994; Anderson 1996). One is the feminist branch, which grew out of women's participation in new left parties in the 1970s and their disillusionment at those parties' incapacity to acknowledge and treat gender discrimination as an issue in and of itself rather than as a secondary problem likely to be solved by the "advent 
of a classless society." The first feminist groups created in the late 1970 s and early 1980 s initially consolidated their identity by isolating themselves from the other social movements or, even more, from political parties. Later, some of them institutionalized themselves by becoming nongovernmental organizations and developed a new vision of feminist politics based on a strategy of addressing the state and seeking to reform discriminatory laws and institutions. In the 1990s, a renewal of movement-based politics, initiated by individual feminists together with women activists and professionals, formed another interesting facet of the movement, parallel to the feminist NGOs.

The second branch consists of a popular sector women's movement, also starting in the late 1970s and taking shape in the mid-1980s with the formation of wide networks of survival organizations based on the need to find solutions to the daily problems of lower-class families. Collective kitchens, organizations providing milk to children and mothers, and other groups formed federations and national coordinating committees to ensure that state or nonstate actors provided staple products and to promote a set of demands seeking the recognition of their autonomous status and contribution as grassroots social organizations led by women.

The third general category is that of the women active in the mainstream political sphere. Women in political parties, unions, and the state bureaucracy became more numerous throughout the 1980s and 1990s. They managed to create women's commissions or divisions in some unions and political parties, as well as to collaborate with the feminists to advocate a number of laws promoting women's equality and rights. The latter development started in the late 1980 s and became a real strength in the 1990 s, after a period marked by confrontations between the feminists and the women politicians.

The end of the 1980s and the 1990s saw a trend for professional women from the women's movement, and civil society organizations in general, to act as individual consultants to the state on a number of issues, such as women's health, violence against women, and microcredit schemes. NGOs also pursued a series of activities to address the political sphere in a nonpartisan fashion. For example, on the question of women's entry into the mainstream political sphere, Foro-Mujer, a coalition made up of six prominent women's NGOs, started lobbying Congress in 1990, and was the first to propose the adoption of electoral gender quotas in 1994. Later, these women's NGOs used the Commission on Women in Congress in a very strategic way to work for bills that advanced women's rights.

The popular sector women's movement, by contrast, suffered during the 1990s from paralysis and later a serious reversal when the state under Fujimori developed a set of agencies that centralized the resources devoted to social assistance and gradually eroded the politi- 
cal capacity of grassroots organizations to remain autonomous and pursue their claims for recognition as social actors representing lowerclass women (Rousseau 2004).

The major victories of the Peruvian women's movement in the 1990s therefore corresponded to the claims and work of the feminist NGOs that had become highly skilled and, for some, well funded. The latter saw a number of gains, explained partly by the support of international donors and the dynamics of the international women's movement.

\section{INTERNATIONAL INFLUENCE}

Intense lobbying and advocacy around the theme "women's rights are human rights" took place at the United Nations World Conference on Human Rights held in Vienna in 1993. Reproductive and sexual rights were then highlighted at the U.N. World Conference on Population and Development in Cairo, 1994. Both conferences preceded the even more important U.N. World Conference on Women, held in Beijing in 1995. Thus the first half of the 1990s represented a historic moment for the mobilization and acknowledgment of the women's movement worldwide.

In Peru, feminist NGOs mobilized themselves around each of these conferences, especially the one in Beijing. For this one, foreign funds, provided partly by the United States Agency for International Development (USAID), allowed the NGOs to instigate a nationwide consultative process leading to the formulation of a comprehensive national public policy agenda on women. The government included prominent NGO women in its delegations to some of the preparatory meetings before the international conferences. A consultation process was also organized by the state in preparation for the Beijing event; it culminated in a major expert seminar. In that seminar, the Justice Ministry's Permanent Commission on Women's Rights collaborated with the Regional NGO Coordinating Committee of Latin America and the Caribbean, led by the prominent Peruvian feminist Virginia Vargas, and the national NGO coalition Grupo Impulsor Nacional.

Thus were some financial resources made available in the 1990s to create national and international networks to insert the voices and claims of the Peruvian women's movement in the international debate on women's rights and the responsibility of the state. The conferences produced "declarations" and "programs of action," which various states signed as a list of commitments. These activities also created new political platforms. The feminist NGOs used these opportunities to highlight the Peruvian state's international obligations and commitments. This process also brought in some congresswomen, some of whom even participated in the Beijing conference either in the official government delegation or individually. 


\section{FUJIMORI's POLITICAL INTEREST IN Promoting "Women's Issues"}

Fujimori was the only head of state to attend the 1995 Beijing World Conference on Women, where he made a vibrant speech in favor of modern family-planning services. The creation of the state institutional opportunities for addressing women's issues followed a few months later. A new policy on reproductive health and family planning, the Programa Nacional de Salud Reproductiva y Planificación Familiar 1996-2000, was also approved in 1995, supposedly in response to the Cairo conference's final report. This apparent willingness to abide by some of the state's commitments under the documents signed at the world conferences contrasted, however, with the regime's blatant disrespect for and frequent violations of numerous international human rights treaties. The state went so far as to retract, in July 1999, its recognition of the Inter-American Court of Human Rights' jurisdiction over Peru.

Still, the most impressive decisions, such as the creation of PROMUDEH, were taken by Fujimori himself in a surprising fashion and without prior consultation with the women's movement (Bermúdez 2001). In light of this haphazard approach, various self-interested motives have been advanced for explaining Fujimori's strategy of promoting women in his political entourage and facilitating the creation of a set of institutions to oversee the improvement of women's status. Some emphasize the president's marital difficulties during his first mandate, which revealed a man who behaved in a very inhuman and machista fashion toward his wife, Susana Higuchi. Higuchi, for her part, denounced the corruption in the government and became an active member of the political opposition. The "Susana case" caused a sudden fall in the president's popularity, especially among the female electorate. Some observers have argued that the development of Fujimori's prowomen discourse, which became much more explicit afterward, was a probable attempt to recuperate his credibility on this terrain (Palomino 2001; Schmidt forthcoming).

Another explanation focuses on the loyalty that a number of highly skilled professional women could offer in return for high-level appointments or inclusion in party lists. Because the power that these positions gave to women depended on the president's will, while the Peruvian political system in general was still relatively adverse to giving women access to powerful positions, the president could count on a number of absolutely loyal representatives (Blondet 2002; Schmidt forthcoming).

Another related factor is the evolution of Peruvian public opinion regarding women politicians. Women's role in the public sphere as administrators, political representatives, and leaders of social organizations was increasingly accepted and valued by Peruvians in the 1990s. 
Surveys repeatedly showed that, especially in the capital, Lima, where a third of all Peruvians live, women were seen as having as much or even more to offer than men in terms of public leadership and responsibility (Blondet 1999b; Alfaro 1998; Calandria 2000). In one such survey in Lima, in 1996, women were described as more sensitive, more honest, and better administrators than men (Alfaro 1996, 10). In the same spirit, when asked to compare male and female mayors, respondents in a 1998 survey indicated that while men work more and are more efficient, women are more honest, loyal, just, and sensitive to social and human issues (Alfaro 1998, 24-25).

Schmidt notes that Fujimori's reliance on public opinion surveys as a technique of political management and his access to the National Intelligence Service's sophisticated public opinion survey infrastructure could very well have played into his decision to increase the number of women in his administration and political parties. The regime's selection of candidates for political and bureaucratic positions was based on, among other factors, a rigorous set of screening tests which, according to Schmidt, would have played more favorably for women than the traditional selection method based on the "old boy networks" (Schmidt forthcoming). Although plausible, this hypothesis should not deny that the opposition parties also welcomed a number of women into their ranks, and some of them became leading political figures.

Some of the policies that mark Fujimori's support for women's movement demands clearly coincided with the regime's overall economic and political strategies. Among the most visible were the advances in providing for stronger public family-planning services, which expanded in the mid-1990s. These provided wider coverage and access to five contraceptive methods, including sterilization surgery, which the Catholic Church strongly opposed. While the president made a number of speeches linking this priority to women's rights' promotion, also explicit was his view that it represented one of the pillars of his poverty-reduction strategy, a prime target of which was to reduce the birth rate.

At the same time, PROMUDEH turned out to be a central piece of the clientelist system engineered through the range of social assistance programs focusing on the poorest sectors of Peruvian society. PROMUDEH, among other agencies, oversaw the National Food Aid Program (Programa Nacional de Asistencia Alimentaria, PRONAA), which was vital for most poor families' daily survival. PRONAA became one of the key tools for the regime's political manipulation of the popular sectors' vote. It affected lower-class women even more than men, because only women participated in grassroots collective kitchens, which increasingly depended on the supply of food staples provided exclusively by PRONAA (Rousseau 2004). 


\section{INSTITUTIONAL FACTORS}

In analyzing the role of political institutions in Peruvian women's breakthrough, an important factor certainly is the weakness of political parties, which is connected to the breakdown of the party system in 1990 and its replacement by personalist electoral coalition movements. The collapse of the party system in Peru is a phenomenon that has received a lot of attention because of the difficulties it poses for democratic consolidation (Cotler 1995; Tanaka 1998; Levitsky and Cameron 2003). Yet in terms of congresswomen's activities on women's issues and the interparty collaboration that was crucial for the adoption of the bills they presented, the low level of party institutionalization seems to have been favorable for adopting legislation on women's rights. This echoes Waylen's comparative analysis of Chile and Argentina in the 1990s, which finds that in Argentina, a weaker party system allowed for more cross-party organizing by elected women (Waylen 2000).

The political space provided to women by a weak party system cannot be understood properly without also referring to the concentration of power in the hands of the executive and to Fujimori's relative autonomy in the face of powerful traditional forces, such as the Catholic Church. A weak party system in itself does not necessarily explain how women and women's issues could gain greater influence in mainstream politics. On the one hand, the president's intervention in the business of Congress, which characterized his rule in general, supported the work of the Commission on Women at some critical junctures, such as the debate on the electoral quotas (Schmidt forthcoming). On the other hand, the Fujimori's unprecedented stand against the church's views on family planning constituted a radical break in Peruvian (and Latin American) politics. ${ }^{7}$ The neutralizing of conservative, Catholic currents represented by some political parties allowed advances that were previously unthinkable.

The positive impact of Fujimori's autonomy on key women's rights issues seems to contradict other conclusions reached by Waylen (2000). She claims that low levels of institutionalization allow for the dominance of elites, which, while it may favor individual women politicians, would not provide for a longer-term increase in women's access to electoral politics. The case of Peru indicates, by contrast, that by neutralizing or diminishing some elite influence in the decisions on electoral quotas and other women's citizenship measures, the low level of institutionalization of politics contributed to favorable outcomes for women. Moreover, the adoption of a 25 percent gender quota for electoral lists was successfully enforced in the 1998 municipal elections and the 2000 and 2001 legislative elections, in a context of very low institutionalization of politics and the authoritarian character of the regime until late 2000. 
These findings are also consistent with the history of Peru, in which major reforms favoring women's citizenship rights were generally passed under authoritarian regimes, be it the conservative government of General Manuel Odría (1948-56), who gave literate women the right to vote in 1955, or the regime of General Juan Velasco (1968-75), the most radical reformer in Peruvian history, which took steps to recognize discrimination toward women (and also granted unprecedented rights to unions, peasants, and indigenous peoples). Echoing this common knowledge in a personal interview, a member of an important Peruvian women's organization expressed the opinion that "reforms stay and regimes go," when asked to comment on this characteristic of Peruvian political history. However, her request not to be identified testifies to the difficult trade-offs the women's movement was facing throughout the 1990s when dealing with the Fujimori regime.

\section{WOMEN'S RIGHTS AND DEMOCRACY: Parallel or Converging Struggles?}

Were women justified in welcoming the regime's apparent willingness to acknowledge some demands of the women's agenda? The women's movement was actually divided on this issue throughout the 1990s, and even more acutely during Fujimori's second term. The emergence of groups such as Mujeres por la Democracia responded to the need for the sectors that opposed any form of collaboration with the regime to find a political expression outside the formal political system. In concrete political terms, treating women's rights as an agenda distinct from the democratization of political institutions could prove counterproductive and become marginalized in the long run. On the other side of the debate, the women who did decide to play by the rules were quite aware of the uncomfortable position they were in, but believed that women's rights had to be fought for above everything. The debate became heated in civil society and in the women's movement as the abuses committed by the regime kept increasing.

By way of illustration, this tension was revealed in a most visible fashion around the 1998 and 2000 elections, when a consortium of women's NGOs developed the project PROMUJER (sponsored by USAID) to train women politicians and disseminate information on the electoral gender quotas adopted in 1997. Although the project remained independent from the state, it became an object of criticism for other sectors of the women's movement struggling against the regime when the undemocratic character of the electoral process was exposed. The mere promotion of women candidates' participation in the elections was seen by many as legitimating a fraudulent process. When all opposition parties decided to participate in the elections-a move criticized by 
many observers - the focus shifted to the "kind" of women candidates PROMUJER was promoting.

Critics argued that the women's NGOs working in PROMUJER, by supporting all women candidates indiscriminately, were encouraging citizens to vote for women who were not proven "democrats"; that is, who were fujimoristas. Promoting a greater presence of women in electoral politics over and above the particular nature of their political affiliation was seen by other women's NGOs, along with other sectors of civil society, as a political mistake. On the other hand, the promoters of PROMUJER often noted that because politicians in general suffered from a lack of public credibility and respect regardless of their political affiliation, it was preferable to vote for women candidates, who, as expressed in public surveys, generally were thought to exhibit fewer tendencies toward corruption. In any case, PROMUJER proponents believed, given that an electoral process existed and a gender quota law had been adopted, it was women's rights activists' duty to make sure that women politicians benefited from their support to perform well and occupy the political space for which they had long fought. ${ }^{8}$

\section{The Limits of A WomeN's Rights AgendA UNDER FUJIMORISMO}

In general, the problems Peruvian women's rights activists experienced throughout the 1990s were related to the strong limits on the rule of law and the politicization of the state embedded in the neopopulist model. On the one hand, this meant that in practice, women had few if any guarantees that the laws and policies they advocated would be implemented. On the other hand, and more dangerously, the conjunction between some of the regime's interests and some of their demands implied that they let the regime benefit from a women-friendly image while, in reality, its policies and practices were often quite antithetical to women's interests.

The promotion of women's political participation in an electoral process that ran contrary to democratic standards of fairness and transparency revealed the contradictions deriving from the broader political framework, in which an authoritarian leader merely used democratic elections to legitimate his rule. The effort to promote women politicians was also used in a most contradictory fashion for the women's movement when, in July 2000 , amid the greatest political crisis of Fujimori's rule, his regime chose a team of four congresswomen to lead the Mesa Directiva, the congress's coordinating body, in a desperate but unprecedented move to attract public support.

A few scandals also proved painful for the women's movement, such as the revelations in 1997 and 1998 that numerous cases of forced sterilization surgery had been performed in public medical clinics. The 
first testimonies gathered by women lawyers from feminist NGOs indicated patterns of pressure, manipulation, misinformation, and coercion of women in poor rural communities, submitting them to sterilization surgery against their will and often with very deficient medical care. Some of these procedures even led to the death of the victims (CLADEM 1999). ${ }^{9}$ A few women's organizations sitting on the Tripartite Working Group on the Follow-up to the Cairo Conference (Mesa Tripartita de Seguimiento a Cairo, an ad hoc consultative body on reproductive health composed of government representatives, NGOs, and international donor agencies), along with most opposition Congresswomen, hesitated to condemn the regime forcefully for these abuses, partly because of the risk of losing all the gains made in family planning (Barrig 2000). Only in 1999 did the Mesa Tripartita issue a public statement acknowledging "certain problems in the quality of the health services performed in some cases."

The concern among women's rights advocates consisted mostly in not wanting to side with the fierce critics of the state family-planning program, such as the Catholic Church and other conservative actors. Fujimori had been the first president to ignore these forces in his decision to invest more resources in family-planning services. While the nonconfrontational attitude of some women's NGOs could be interpreted as indicative of a clientelistic relation between these sectors of the women's movement and the state, a closer look reveals that it amounted to a pragmatic, strategic stance. Indeed, the fragile political backing of the familyplanning program and the absence of institutionalized procedures that could guarantee the survival of the program's broad objectives were real constraints facing these women's organizations.

Nevertheless, a more radical sector of the women's movementthrough the Movimiento Amplio de Mujeres (MAM), another group formed in the mid-1990s to oppose the authoritarian character of the Fujimori regime-took to the streets to protest the abuses. MAM publicly denounced the acts of intimidation committed against the feminist lawyer who had been central in gathering the first testimonies of victims and against some of the victims who had brought their cases to court. The international concern these actions also raised forced the Fujimori government to revise the procedure manual for public health practitioners; but greater clarification of criminal or administrative responsibilities could not be addressed until a change in government.

The limits of Fujimori's women-friendly discourse are also revealed by an analysis of his regime's policies and their differential impact on various social classes. The neoliberal reforms Fujimori implemented during the first months of his rule dramatically hit the poorest sectors, which already were only barely surviving. Rigorous structural adjustment measures and labor law deregulation put thousands of state and 
nonstate workers on the streets. This increased the pressure on the social safety net, which also suffered a radical reshaping through the privatization of a number of basic services. Estimates by Instituto Cuanto and UNICEF of the portion of households in poverty changed from 38 percent in 1985 to 55 percent in 1991 and 48 percent in 1994, while the percentage of households in extreme poverty went from 15 percent in 1985 to 24 percent in 1991 and 18 percent in 1994 (cited in Sheahan 1999, 108). Even if Fujimori can be credited for engineering the recuperation of the Peruvian economy, a majority of the population had to rely on food aid at least weekly, if not daily, and precarious informal sector employment became the norm (Henríquez 1999).

Women throughout Latin America have been affected more drastically than men by the adoption of the neoliberal development model and its implications for the role of the state in the provision of social welfare, and Peru is no exception (Craske 1998). Thus the record of the Fujimori era from the point of view of the rights and priorities of lowerclass women, who have increased in proportion to the total population in the wake of neoliberal adjustment and liberalization, is rather bleak. Whereas the preceding Peruvian governments, at least since the return to democratic rule in 1980, all attempted (and partly succeeded) to use food aid as a basis for constructing a political clientele among poor women, Fujimori managed to centralize all sources of food donations through the National Food Aid Program, PRONAA, which exercised an unprecedented level of control over women's grassroots organizations, especially around election time.

The power of state officials through the local food aid distribution centers even led them to intervene in the leadership selection of those organizations, creating divisions in many neighborhoods (Cubas 2001; Cuentas 2001). The networks of grassroots survival-based organizations, which had gained in strength in the 1980s, including the collective kitchens (comedores populares) and the Glass of Milk committees (Vaso de leche), where women from popular sectors were most active, spent much energy resisting these encroachments on their autonomy. Instead of expanding their power base and becoming a social force representing lower-class women's interests, they remained trapped by their dependence on food staples and their struggle to protect their basic functions.

The difficulties experienced by popular sector women's organizations were somewhat compensated when, at the end of the 1990s, a few women leaders from Lima's popular sectors moved upward by. becoming candidates in municipal or legislative elections; some even got elected. But the absence of political venues for discussing social and economic reforms meant very limited gains, if any, for lower-class women's citizenship rights. Some feminist activists acknowledged the limits of the strategies implemented by the main women's NGOs during 
the 1990s, which corresponded primarily to an entitlement agenda rather than a participatory platform for grassroots women's empowerment. These strategies thus revealed a great gap between the advances made and the need for major structural changes for the majority of women to benefit from them (Vargas 2002).

\section{Conclusions}

The legitimacy gained by some sectors of the women's movement through its many years of campaigning created the essential background for the Fujimori regime to present a political opportunity to advance some of the issues on the women's agenda. This study has shown that Fujimori's particular interest in women as a political clientele was a key "intervening variable." Indeed, without the president's decision to move favorably on most of these issues, it is uncertain whether even part of these gains could have been made.

The institutional framework Fujimori created in the wake of his selfcoup, moreover, facilitated the adoption of some of these reforms by concentrating the political power in the president's hands. A parallel can therefore be traced between neopopulist regimes' capacity to implement neoliberal economic reforms against the will of the majority of significant political actors, and their capacity to counter entrenched opposition to state intervention in favor of greater gender equality. Indeed, by neutralizing established channels of opposition and representation of interests, a neopopulist pattern of rule allows difficult reforms to be adopted (Roberts 1995; Weyland 1996).

In this regard, the renewal of the terms of political representation without the power of traditional political forces can be positively associated with the greater political opportunities that Peruvian women gained, along with some progress in civil rights. The centralization of power in the hands of the executive and the weakness of representative institutions, accompanied by a severe crisis in the political party system, meant that the all-powerful leader's decision to use some of the women's movement's agenda allowed or directly led to the creation of new institutions dealing specifically with issues of concern to women. The influence of the international agenda on women's rights and the potential support from the international donor community were positive incentives to Fujimori on these issues.

Yet the authoritarian features of the Fujimori regime posed an ethical and practical dilemma for the majority in the women's movement who had to live with the trade-offs associated with a neopopulist, authoritarian framework. The question of how much women could benefit from the openings on women's rights without losing their credibility in democratic circles was a real challenge for the Peruvian women's 
movement. A number of events, moreover, revealed the danger of state intervention in the name of women's promotion when there were no solid institutions abiding by the rule of law and respecting human rights. Women's rights advocates risked losing popular support for their proposals when those proposals were used partly for political gain by the regime and therefore lacked the appropriate means for democratic, transparent, and participatory implementation.

The gains made in some aspects of women's citizenship were, with the exception of the family-planning program, generally circumscribed to the field of civil and political rights. While they indisputably constitute fundamental gains, the outcome in terms of social and economic rights was much less positive. While the majority of women remained poor and excluded throughout Fujimori's rule, women's organizations in popular sectors lost some of their capacity to act as autonomous political actors because of the regime's centralization and manipulation of food aid.

The neopopulist character of fujimorismo therefore had serious negative implications for the politics of women's citizenship in Peru. Moreover, the key to understanding the relationship between neopopulist rule and the kinds of advances that were made on behalf of women is the weakness of organized civil society. The gains made by the women's movement were related to its capacity to lobby rather than to exert political pressure through mass mobilization. Neopopulist rule, from this perspective, was not only a cause but also a reflection of multiple processes of fragmentation and weakening that affected Peruvian civil society in the 1990s, including some sectors of the women's movement.

One could conclude that the advances made in Peruvian women's citizenship are vulnerable in the long run because they were strongly associated with the power of an authoritarian leader rather than with a consensus emerging from the normal workings of democratic political institutions. Yet they may prove more enduring, because they were grounded in proposals of women's organizations in civil society that preceded the regime and did not end with it. By way of example, the gender quota for electoral lists was raised from 25 to 30 percent by Congress during the post-Fujimori transition government, for the $2001 \mathrm{elec}-$ tions; this seems to indicate that the overall performance of women in politics continues to be perceived as positive in the eyes of not only the majority of Peruvians, but also of its political class.

\section{NoTES}

This article stems from a doctoral dissertation project that included personal interviews with more than 35 Peruvian women activists, politicians, and academics. Interviews were conducted in Lima in 2000 and 2001. Individual names have been kept confidential in this article. 
An earlier version of this work was presented at the annual meeting of the Canadian Association of Latin American and Caribbean Studies, Montreal, October 24-26, 2002. The author wishes to thank Philip Oxhorn and the anonymous reviewers for their comments, and Cecilia Blondet for her invitation to be a visiting fellow at the Instituto de Estudios Peruanos in 2001 and her advice at various stages of the research. The Fonds Concerté d'Aide à la Recherche (Québec), the Social Sciences and Humanities Research Council of Canada, and McGill University provided financial support for field research.

1. In April 1992, democratically elected President Fujimori perpetrated what has been labeled an autogolpe (self-coup), closing down the legislative institutions, arresting some opposition politicians and deputies, abrogating the 1979 Constitution, and imposing a regime dominated by an alliance with the military and the intelligence services. Reluctantly and under international pressure, Fujimori called elections for a Constituent Congress in 1993 in which most opposition parties abstained from participating.

2 . Weyland finally opts for restricting the notion to a purely political concept, thereby restoring the validity of the notion of populism for describing past and current forms of populist rule while delinking it from any economic policy model (Weyland 2001). This study posits the usefulness of the notion of neopopulism for emphasizing the rise of different modes of political representation, such as the absence of significant institutionalized channels for mass mobilization like political parties, and their replacement by modern techniques to monitor public support and shape public opinion; surveys and mass media, for example.

3. As an indication of this trend, the number of women cabinet ministers increased from zero in 1980-85 to 3.9 percent in 1985-90, 4.6 percent in 1990-95, and 7.5 percent in 1995-99; the last two periods correspond to Fujimori's government (Blondet 2002, 78). Similarly, women deputy ministers were absent in 1983 and 1987-88 (when data were available), but then represented 15.8 percent in 1995 under Fujimori (Klatzer 2000, 219).

4. In 2000 , women represented 25.8 percent of the candidates of Fujimori's Peru 2000 and won 28.8 percent of the party's seats. In comparison, women formed 25.9 percent of the candidates in opposition parties' lists who won seats, but occupied only 16.2 percent of their seats. The better performance of women in Fujimori's lists was evident throughout the 1990s except in 1995, when women on opposition party lists fared slightly better (Schmidt forthcoming).

5. The quota was increased to 30 percent in 2001 for both congressional and municipal elections.

6. In the 2001 general elections following the fall of the Fujimori regime, however, the portion of women elected dropped to 18 percent, partly because of changes in the magnitude of districts (see Rousseau 2005).

7. It should be noted that this confrontation was instrumental in Fujimori's effort to divert attention from the church's open criticism of the regime's human rights violations, as reported in Conaghan 2000.

8. This summary of the debate is based on the arguments presented by various women's NGO staff and women activists, in personal interviews with the author carried out in 2000 and 2001.

9. The investigation carried out by the NGO Comité Latino-Americano sobre los Derechos de la Mujer (CLADEM) reported 243 cases of human rights 
violations committed in the context of surgical sterilization, causing victims to be sterilized without giving their informed consent (CLADEM 1999). Other investigations were later carried out by the Defensoría del Pueblo and by a special commission of the Peruvian Ministry of Health (under the current government of Alejandro Toledo). The latter reported that of the 2,096 clinical reports it studied, women in $\mathbf{2 5 . 1}$ percent had not given their informed consent, and in 34.2 percent the official procedures for obtaining women's consent had not been followed properly by medical staff. See Comisión Especial sobre Actividades de Anticoncepciôn Quirúrgica Voluntaria 2002, 94.

\section{REFERENCES}

Alfaro, Rosa-María. 1996. Mundos de renovación y trabas para la acción pública de la mujer. Lima: Asociaciones de Comunicadores Sociales Calandria.

- 1998. Una vida cotidiana sembrada de conflictos. Opinión pública e igualdad de género. Lima: Asociaciones de Comunicadores Sociales Calandria.

Alvarez, Sonia. 1990. Engendering Democracy in Brazil: Women's Movements in Transition Politics. Princeton: Princeton University Press.

Anderson, Jeanine. 1996. Gobiernos inmerecidos: la mujer peruana y el estado en el Perú. In Triângulo de poder, ed. Geertje Lycklama Nijeholt, Virginia Vargas, and Saskia Wieringa. Bogotá: Tercer Mundo. 271-308.

Asociación Civil Transparencia. 2000. Una bistoria que no debe repetirse. Perui: elecciones generales 2000. Informe de observación electoral. Lima: Transparencia.

Asociaciones de Comunicadores Sociales Calandria. 2000. Buscando la equidad en el congreso. Encuesta sobre participacion politica de la mujer. Lima: Calandria.

Barrig, Maruja. 1994. The Difficult Equilibrium Between Bread and Roses: Women's Organizations and Democracy in Peru. In The Women's Movement in Latin America: Participation and Democracy, 2nd ed., ed. Jane Jaquette. Boulder: Westview Press. 151-75.

- 2000. La persistencia de la memoria. Feminismo y estado en el Perú de los 90. Lima: Pontificia Universidad Católica del Perú.

Bermúdez, Violeta. 2001. Former Coordinator, NGO Movimiento Manuela Ramos. Author interview. Lima, May 15.

Blondet, Cecilia. 1998. La emergencia de las mujeres en el poder. ¿Hay cambios? Lima: Instituto de Estudios Peruanos.

-. 1999a. Las mujeres y la politica en la década de Fujimori. Lima: Instituto de Estudios Peruanos.

— $1999 \mathrm{~b}$. Percepción ciudadana sobre la participación política de la mujer. El poder político en la mira de las mujeres. Lima: Instituto de Estudios Peruanos.

- 2002. El encanto del dictador. Mujeres y política en la década de Fujimori. Lima: Instituto de Estudios Peruanos.

Cameron, Maxwell, and Philip Mauceri, eds. 1997. The Peruvian Labyrintb: Polity, Society, Economy. University Park: Pennsylvania State University Press.

Carrión, Julio. 2001. Understanding Electoral Authoritarianism: The Case of the 1995 Election in Peru. Paper presented at the Annual Meeting of the American Political Science Association, San Francisco, August 30-September 2. 
Comisión Especial sobre Actividades de Anticoncepción Quirúrgica Voluntaria. 2002. Informe final. Lima: Ministerio de Salud, República del Perú.

Comité de América Latina y el Caribe para la Defensa de los Derechos de la Mujer (CLADEM). 1999. Nada personal. Reporte de derechos humanos sobre la aplicación de la anticoncepción quinírgica en el Pení 1996-1998. Lima: CLADEM.

Conaghan, Catherine. 2000. The Irrelevant Right: Alberto Fujimori and the New Politics of Pragmatic Peru. In Conservative Parties, the Right, and Democracy in Latin America, ed. Kevin Middlebrook. Baltimore: Johns Hopkins University Press. 255-85.

Cotler, Julio. 1995. Political Parties and the Problems of Democratic Consolidation in Peru. In Building Democratic Institutions: Party Systems in Latin America, ed. Scott Mainwaring and Timothy Scully. Stanford: Stanford University Press. 323-53.

Cotler, Julio, and Romeo Grompone. 2000. El fujimorismo: ascenso y caída de un régimen autoritario. Lima: Instituto de Estudios Peruanos.

Craske, Nikki. 1998. Remasculinisation and the Neoliberal State in Latin America. In Gender, Politics and the State, ed. Vicky Randall and Georgina Waylen. London: Routledge. 100-120.

Cubas, Gloria. 2001. Program Officer, Peruvian NGO Alternativa. Author interview. Lima, May 9.

Cuentas, Martha. 2001. Executive Director, Peruvian NGO FOVIDA. Author interview. Lima, February 21.

Dános Ordóñez, Jorge. 2000. Los derechos a la igualdad y no discriminación por razón de sexo en el derecho constitucional. In Discriminación sexual y aplicación de la ley, Volúmen IV: Derecho penal y constitucional Lima: Defensoría del Pueblo.

Diamond, Larry. 1996. Is the "Third Wave" Over? Journal of Democracy 7, 3: 20-37. Friedman, Elisabeth. 2000. Unfinished Transitions: Women and the Gendered Development of Democracy in Venezuela, 1936-1996. University Park: Pennsylvania State University Press.

Henríquez, Narda, ed. 1999. Construyendo una agenda social. Lima: Pontificia Universidad Católica del Perú.

Htun, Mala, and Mark Jones. 2002. Engendering the Right to Participate in Decision-making: Electoral Quotas and Women's Leadership in Latin America. In Gender and the Politics of Rights and Democracy in Latin America, ed. Nikki Craske and Maxine Molyneux. New York: Palgrave. 32-56.

Jaquette, Jane, ed. 1989. The Women's Movement in Latin America: Feminism and the Transition to Democracy. Boulder: Westview Press.

1994. The Women's Movement in Latin America: Participation and Democracy. 2nd ed. Boulder: Westview Press.

Jaquette, Jane, and Sharon Wolchik, eds. 1998. Women and Democracy: Latin America and Central and Eastern Europe. Baltimore: Johns Hopkins University Press.

Levitsky, Steven. 1999. Fujimori and Post-Party Politics in Peru. Journal of Democracy 10, 3: 78-92.

Levitsky, Steven, and Lucan Way. 2002. The Rise of Competitive Authoritarianism. Journal of Democracy 13, 2 (April) : 51-65. 
Levitsky, Steven, and Maxwell A. Cameron. 2003. Democracy Without Parties? Political Parties and Regime Change in Fujimori's Peru. Latin American Politics and Society 45, 3 (Fall): 1-33.

McClintock, Cynthia. 1999. ¿Es autoritario el gobierno de Fujimori? In El juego político. Fujimori, la oposición y las reglas, ed. Fernando Tuesta Soldevilla. Lima: Ebert Stiftung Foundation. 65-96.

Merino, Beatriz. 2001. Former representative, Peruvian Congress (notably 1995-2000). Author interview. Lima, May 18.

Oxhorn, Philip. 1998. Social Inequality, Civil Society and the Limits of Citizenship. Paper presented at the 14 th World Congress of Sociology, Montreal, July 26-August 1 .

Palomino, Rocio. 2001. Analyst of the Peruvian women's movement; former member, Peruvian NGO Centro de Estudios Sociales y Publicaciones. Author interview. Lima, February 13.

Roberts, Kenneth. 1995. Neoliberalism and the Transformation of Populism in Latin America: The Peruvian Case. World Politics 48 (October): 82-116.

Rospigliosi, Fernando. 1995. La amenaza de la fujimorización. Gobernabilidad y democracia en condiciones adversas: Perú y los países andinos. In Partidos y clase política en América Latina en los 90, ed. Carina Perelli, Sonia Picado, and Daniel Zovatto. San José: Instituto Interamericano de Derechos Humanos CAPEL. 311-34.

Rousseau, Stéphanie. 2001. Women in the Peruvian Parliament: Advances and Contradictions in a Troubled Political Scene. Paper presented at the Seminar "Women in Parliament: Influencing Change?" Queen's University, Belfast, October 26-27.

- 2004. Women and the Public Sphere in Peru: Citizenship Under Fujimori's Neopopulist Rule. Ph.D. diss., McGill University.

- 2005. Peru. In Sharing Power: Women, Parliament and Democracy, ed. Yvonne Galligan and Manon Tremblay. Aldershot: Ashgate. 91-105.

Schmidt, Gregory. 2000. Delegative Democracy in Peru? Fujimori's 1995 Landslide and the Prospects for 2000. Journal of Interamerican Studies and World Affairs 42, 1 (Spring): 99-132.

—. Forthcoming. All the President's Women: Fujimori and Gender Equity in Peruvian Politics. In The Fujimori Legacy: The Rise of Electoral Authoritarianism in Peru, ed. Julio Carrión. University Park: Pennsylvania State University Press.

Sheahan, John. 1999. Searching for a Better Society: The Peruvian Economy from 1950. University Park: Pennsylvania State University Press.

Stokes, Susan. 1996. Peru: The Rupture of Democratic Rule. In Constructing Democratic Governance: South America in the 1990s, ed. Jorge I. Domínguez and Abraham Lowenthal. Baltimore: Johns Hopkins University Press. 58-71.

Tanaka, Martín. 1998. Los espejismos de la democracia. El colapso del sistema de partidos en el Peri, 1980-1995, en perspectiva comparada. Lima: Instituto de Estudios Peruanos.

Vargas, Virginia. 2002. The Struggle by Latin American Feminisms for Rights and Autonomy. In Gender and the Politics of Rights and Democracy in Latin America, ed. Nikki Craske and Maxine Molyneux. New York: Palgrave. 199-221. 
Vargas, Virginia, and Victoria Villanueva. 1994. Between Confusion and the Law: Women and Politics in Peru. In Women and Politics Worldwide, ed. Barbara Nelson and Najma Chowdhury. New Haven: Yale University Press. 576-89. Waylen, Georgina. 1994. Women and Democratization: Conceptualizing Gender Relations in Transition Politics. World Politics 46 (April): 327-54. 2000. Gender and Democratic Politics: A Comparative Analysis of Consolidation in Argentina and Chile. Journal of Latin American Studies 32, 3: $765-93$.

Weyland, Kurt. 1996. Neopopulism and Neoliberalism in Latin America: Unexpected Affinities. Studies in Comparative International Development 31, 3: 3-31.

- 1999. Neoliberal Populism in Latin America and Eastern Europe. Comparative Politics 31, 4: 379-401.

- 2001. Clarifying a Contested Concept: Populism in the Study of Latin American Politics. Comparative Politics 34, 1: 1-22. 